\title{
Implementation of Fuzzy AHP Method to Determine the Best Alternative of Electric Energy Source for RKEF PT Vale Indonesia
}

\author{
Muhammad Ridwan and Udisubakti Ciptomulyono \\ Department of Industrial and Systems Engineering, Institut Teknologi Sepuluh Nopember, Surabaya \\ e-mail: ridwan.tandiara@gmail.com
}

\begin{abstract}
Abstrak-PT. Vale Indonesia is planning to build a RKEF to produce an additional $10 \mathrm{kT}$ of nickel in a year. The $70 \mathrm{MW}$ RKEF power requirement will be met from excess power from 3 hydro power plant and an additional $20 \mathrm{MW}$ from other power plants. The selection of additional power plants is complicated because the selection process involves multiple conflicting criteria that can be either qualitative or quantitative, therefore a MCDM approach is carried out to obtain the best alternative by ranking according to criteria with regards to their relative importance and calculating weight of each criterion. Furthermore, the selection of the best alternative power plants will use the analogy between AHP and the geometric mean Fuzzy AHP method to choose a power plant. This selection is managed using six criteria, namely the price of electricity or LCOE, funding sources for investment costs, the effect of greenhouse gases, availability of resources, effects to the operations to the processing plant and utilities, and the duration of the project. There are 4 alternatives compared, namely PLTD, PLTS, ORC and PLTA, and the results of the selection show that PLTA has the highest value and was chosen as the best alternative.
\end{abstract}

Keywords—Fuzzy AHP, Power Plant, Criterion Alternative.

\section{INTRODUCTION}

$P^{\mathrm{T}}$ T. VALE Indonesia is a nickel mining company operating on Sulawesi island of Indonesia under a contract of work with Government of Indonesia. Contract of work area of PT. X is about 118,017 hectares. PT. X operates mining and nickel processing plant that produce nickel matte which contain around $78 \%$ nickel and $20 \%$ sulfur.

In carrying out nickel ore processing operations, PT. X owns and operates three hydropower facilities (Larona PP, Balambano PP and Karebbe PP) with a total average capacity of 365 megawatts (MW) based on PT X Power Generation Data in 2018 [1]. Besides that, PT. Vale Indonesia also has thermal power generation facilities consisting of 5 MBDG@6 MW diesel generators and 23 Caterpillar@1 MW diesel generators, but due to NOx emission produced by those generators exceed limitation of government regulation so that they can be run only for 1,000 hours in a year.

\section{A. Background}

As part of the work contract amendment, the company plans to increase nickel production. The strategic step taken is the development of a processing plant facility in Sulawesi to reach the target by 2024 PT Vale Indonesia has to have a

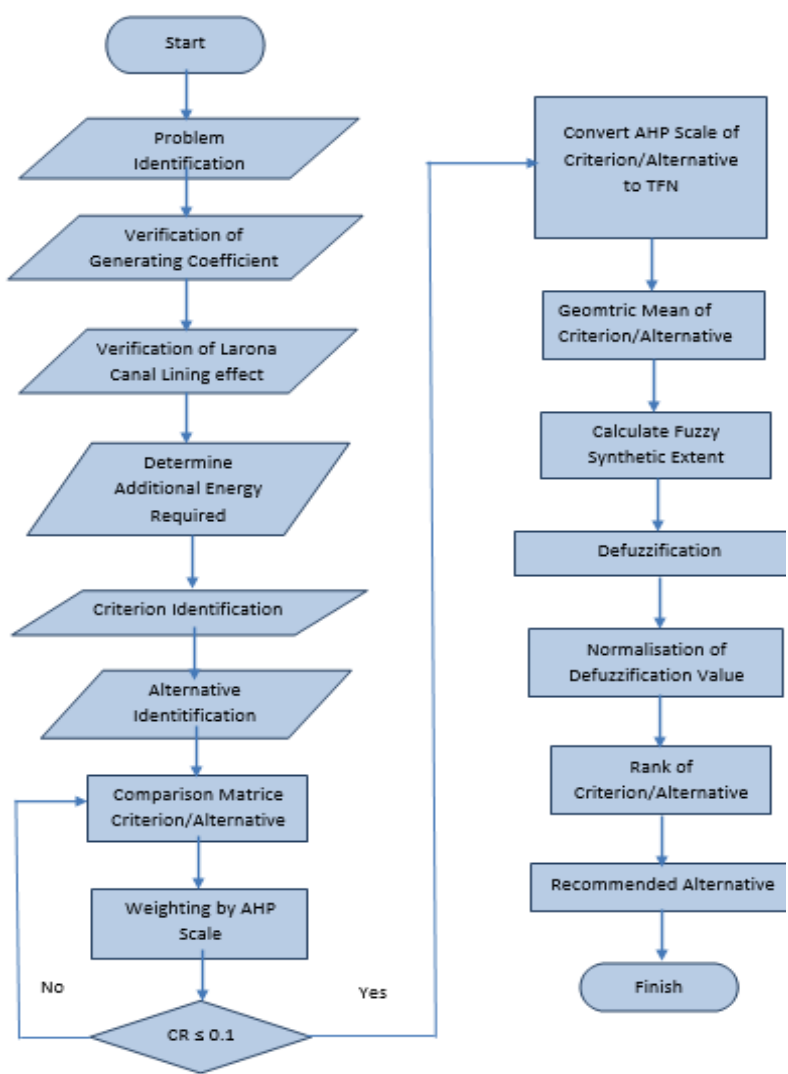

Figure 1. Flow Diagram of AHP Fuzzy Method.

nickel matte production capacity of 90,000 tons (90 kT) in a year.

To reach $90 \mathrm{kT}$, it is currently assumed that the annual production of existing furnaces is $75 \mathrm{kT}$, so an additional 15 $\mathrm{kT}$ is required to reach $90 \mathrm{kt}$. It is targeted that by implementing certain Continuous Improvement projects an additional $2.5 \mathrm{kT}$ will be obtained, on the other hand using high nickel ore obtained from the Bahodopi Block \# 1 is targeted to be an additional $2.5 \mathrm{kT}$, so that it is expected to obtain an additional $5 \mathrm{kT}$ from both businesses and there are still $10 \mathrm{kT}$ to be achieved to get a total of $90 \mathrm{kT}$. An additional $10 \mathrm{kT}$ will be obtained by build one new RKEF system in Soroako. To produce the additional $10 \mathrm{kT}$ nickel by RKEF, it will require large amounts of electricity around $70 \mathrm{MW}$. At present the electricity needs are supplied from power plants that are currently owned, such as from hydropower and diesel generator. 
The $6^{\text {th }}$ International Seminar on Science and Technology (ISST) 2020

July $25^{\text {th }}, 2020$, Institut Teknologi Sepuluh Nopember, Surabaya, Indonesia

Table 1.

Random Index Matric

\begin{tabular}{lllllllllll}
\hline Matrix Order & 1 & 2 & 3 & 4 & 5 & 6 & 7 & 8 & 9 \\
Random Index & 0 & 0 & 0.58 & 0.90 & 1.12 & 1.32 & 1.41 & 1.49 & 1.51 & 1.59 \\
\hline \hline
\end{tabular}

Table 2 .

AHP Scale and Fuzzy AHP Triangular Fuzzy Number [5]

\begin{tabular}{cccl}
\hline $\begin{array}{c}\text { AHP } \\
\text { Scale }\end{array}$ & Fuzzy TFN & $\begin{array}{c}\text { Invers } \\
\text { Fuzzy TFN }\end{array}$ & \\
\hline 1 & $(1,1,1)$ & $(1,1,1)$ & Both elements are Equally important \\
2 & $(1,2,3)$ & $(1 / 3,1 / 2,1)$ & $\begin{array}{l}\text { Intermediate Preference } \\
\text { One element is Moderately More Important than the other element }\end{array}$ \\
3 & $(2,3,4)$ & $(1 / 4,1 / 3,1 / 2)$ & $\begin{array}{l}\text { OnP Scale and Fuzzy AHP Triangular Fuzzy Number [5] } \\
4\end{array}$ \\
5 & $(3,4,5)$ & $(1 / 5,1 / 4,1 / 3)$ & Intermediate Preference \\
6 & $(5,6,7)$ & $(1 / 6,1 / 5,1 / 4)$ & One element is Strongly More important than the other element \\
7 & $(6,7,8)$ & $(1 / 8,1 / 6,1 / 5)$ & Intermediate Preference \\
8 & $(7,8,9)$ & $(1 / 9,1 / 8,1 / 7)$ & One element is Very Strong More Important than the other element \\
9 & $(8,9,9)$ & $(1 / 9,1 / 9,1 / 8)$ & One element is Extremely more important than the other element \\
\hline \hline
\end{tabular}

Table 3.

Generating Coefficient of Larona Hydro Power Plant

\begin{tabular}{lccc} 
& \multicolumn{2}{c}{ Generating Coefficient of Larona Hydro Power Plant } \\
\hline \hline Hydro Power Plant & \multicolumn{2}{c}{ Generating Coefficient (MW/cumecs) } & \multicolumn{2}{c}{$\begin{array}{c}\text { Power Generation for 148 cumecs } \\
\text { Before Verification }\end{array}$} & After Verification & Before Verification & After Verification \\
\hline PLTA Larona & 1.12 & 1.22 & $165.7 \mathrm{MW}$ \\
\hline \hline
\end{tabular}

Table 4.

Water Balance Hydro Power Plant Generation after Canal Lining

\begin{tabular}{|c|c|c|c|c|c|c|}
\hline \multirow{2}{*}{$\begin{array}{l}\text { Hydro Power Plant } \\
\text { (PLTA) }\end{array}$} & \multirow{2}{*}{$\begin{array}{c}\text { Generating } \\
\text { Coefficient } \\
\text { (MW/cumecs) }\end{array}$} & \multirow{2}{*}{$\begin{array}{l}\text { Additional Flow } \\
\text { (cumecs) }\end{array}$} & \multicolumn{2}{|c|}{$\begin{array}{c}\text { Larona Canal Flow } \\
136 \text { cumecs }\end{array}$} & \multicolumn{2}{|c|}{$\begin{array}{c}\text { Larona Canal Flow } 148 \\
\text { cumecs }\end{array}$} \\
\hline & & & $\begin{array}{c}\text { Flow } \\
\text { (cumecs) }\end{array}$ & $\begin{array}{l}\text { Power } \\
(\mathrm{MW})\end{array}$ & $\begin{array}{c}\text { Flow } \\
\text { (cumecs) }\end{array}$ & $\begin{array}{l}\text { Power } \\
(\mathrm{MW})\end{array}$ \\
\hline PLTA Larona & 1.22 & 0 & 136 & 165 & 148 & 180 \\
\hline PLTA Balambano & 0.76 & 5 & 141 & 107 & 153 & 116 \\
\hline PLTA Karebbe & 0.67 & 3 & 144 & 96 & 156 & 104 \\
\hline Power & & & & 368 & & 400 \\
\hline
\end{tabular}

\section{B. Problem Identification}

Basically, the additional power demand can be fulfilled by diesel generator own but due to NOx emission produced by those generators exceed limitation of government regulation so that they can be run only for 1,000 hours in a year. Based on the Minister of Environment and Forestry regulation number 15 of 2019[2], the maximum threshold value of NOx produced by diesel generators with a capacity of more than 3 MW is a maximum of $1,200 \mathrm{mg} / \mathrm{Nm} 3$ whereas the MBDG produces NOx 1800-3100 mg/Nm3 and for diesel generators capacity of less than $3 \mathrm{MW}$ has a maximum limit at 1,400 mg/Nm3 whereas Caterpillar produces NOx 2700-3100 $\mathrm{mg} / \mathrm{Nm} 3$.

There are some issues should be fixed before continuing to Fuzzy AHP method to determine the best criteria and the alternative of power. The issues are:

1. Verification of Larona generating coefficient. There is a doubt about how big the actual capacity of the hydroelectric power plant when the water balance scenario is being run.

2. Verification the impact of Larona canal lining project for increment of existing hydro power plant capacity in water balance scenario. Since completion in May 2019, the new Larona canal capacity has never been tested.

3. Verification of existing auxiliary power demand and future power demand, including the power saving that can be obtained by several projects.

4. Colleting some data about potential electrical energy source around Soroako PT Vale Indonesia.

\section{FUZZY AHP}

Fuzzy AHP method is a development of the AHP method which is part of the decision making multi criteria method in the quantitative model category. The Fuzzy AHP method changes the scale of the AHP into a triangular fuzzy scale to obtain priority. Furthermore, according to Chang the modified data was further processed with extent analysis [3]. The questionnaire data of each respondent was first tested for consistency ratio using the AHP method before the data of each respondent was changed on the TFN scale. To get the result of consistency ratio of each data provided by respondents, it will go through stages by referring to the formula below. 
The $6^{\text {th }}$ International Seminar on Science and Technology (ISST) 2020

July $25^{\text {th }}, 2020$, Institut Teknologi Sepuluh Nopember, Surabaya, Indonesia

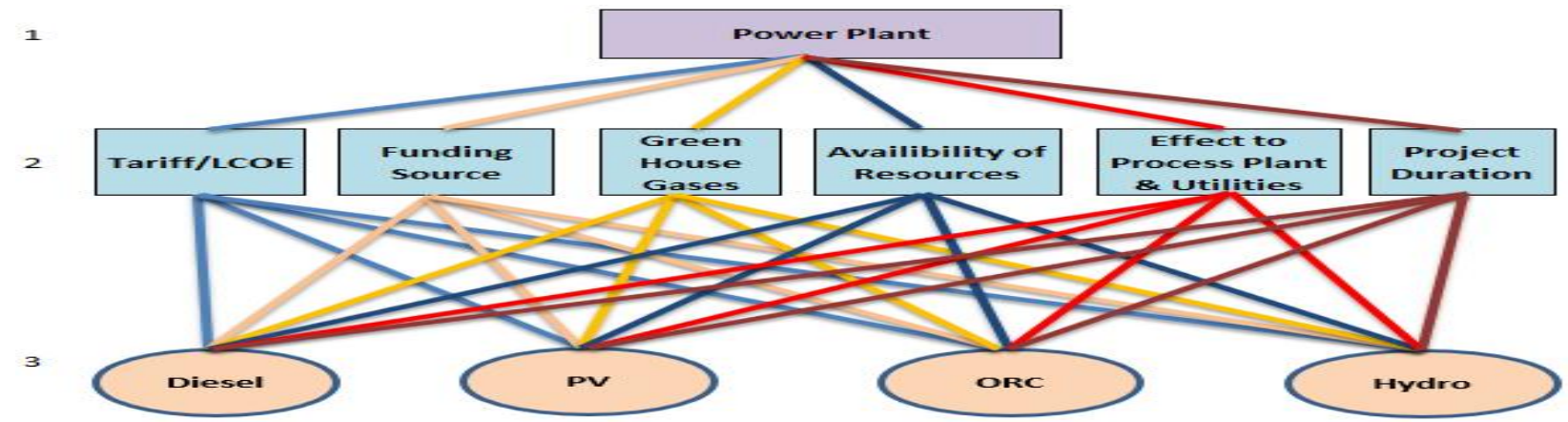

Figure 2. Analytic Hierarchy Process Scheme for Selection of Alternative Power Plant.

\begin{tabular}{|c|c|c|c|c|c|}
\hline \multirow{2}{*}{ Power Generations \& Loads } & \multicolumn{4}{|c|}{ Water Balance (MW) - Option } & \multirow{2}{*}{$\begin{array}{l}\text { PEAK (MW) - } \\
\text { Water } \\
\text { Unbalance \& } \\
\text { Equipment }\end{array}$} \\
\hline & $\mathbf{1}$ & 2 & $\mathbf{3}$ & 4 & \\
\hline Larona & 180 & 180 & 180 & 180 & 186.0 \\
\hline Balambano & 116 & 116 & 116 & 116 & 140.0 \\
\hline Karebbe & 104 & 104 & 104 & 104 & 127.4 \\
\hline Total Hydro Power - Generated & 400 & 400 & 400 & 400 & 453.4 \\
\hline Transmission Line Losses $[2 \%]$ & 6.81 & 6.75 & 6.75 & 6.57 & 6.75 \\
\hline Hydro Alus Load & 0.5 & 0.5 & 0.5 & 0.5 & 0.5 \\
\hline PLN-from Hydro & 5 & 5 & 5 & 5 & 5 \\
\hline Government - from Hydro & 3 & 3 & 3 & 3 & 3 \\
\hline Total Hydro Power-Deducted. & 15.3 & 15.3 & 15.3 & 15.1 & 15.3 \\
\hline Total Power Delivered to Plant Site & 384.7 & 384.7 & 384.7 & 384.9 & 438.1 \\
\hline Furnace & 280 & 280 & 280 & 271 & 280 \\
\hline Ausiliary Load \& Perea Line & 45 & 45 & 45 & 45 & 45 \\
\hline PLN Soroako-from Aus Grid & 2.7 & 2.7 & 2.7 & 2.7 & 2.7 \\
\hline Eleotrio Boiler & 13 & 10 & 10 & 10 & 10 \\
\hline $\begin{array}{l}\text { Furnace Bandwidth } \\
\text { ('W'ter Balanoe Spinning Reserve Setting) }\end{array}$ & 20 & 20 & 5 & 5 & 5 \\
\hline Future Load & $\mathrm{o}$ & 0 & 5 & 5 & 5 \\
\hline Saving of PowerlEnergy & o & o & [4] & [4] & [4] \\
\hline Total Load at Plansite. & 360.7 & 357.7 & 343.7 & 334.7 & 343.7 \\
\hline Others Source (power plant) & 0 & 0 & 29 & 20 & 0 \\
\hline Other Power Plant & $\mathbf{0}$ & o & 29 & 20 & o \\
\hline Total Power Generation & 400 & 400 & 429 & 420 & 453.4 \\
\hline Total Loads and Losses & 376.0 & 373.0 & 359.0 & 349.8 & 359.0 \\
\hline AVAILABLE POWER FOR RKEF (W/B) & 24.0 & 27.0 & 70.0 & 70.2 & \\
\hline AVAILABLE POWER FOR RKEF (W/UB) & 77.4 & 80.4 & 94.4 & 103.6 & $\mathbf{9 4 . 4}$ \\
\hline RKEF LOADS & 70 & 70 & 70 & 70 & 70 \\
\hline Total Spinning Reserve WUB (MW) & 27.4 & 30 & 29.4 & 38.6 & 29.4 \\
\hline Percentage of Spinning Reserve WUB (\%) & 6.0 & 6.7 & 6.9 & 8.5 & 6.5 \\
\hline
\end{tabular}

Figure 3. PTVI Power Generation and Load 2019 and Future 2023.

A. Provide Pairwise Matric for Each Questionnaire from Each Respondent

$\mathrm{A}=\left[\begin{array}{ccccc}a_{11} & a_{12} & a_{13} & \ldots & a_{1 n} \\ a_{21} & a_{22} & a_{23} & \ldots & a_{2 n} \\ a_{31} & a_{32} & a_{33} & \ldots & a_{3 n} \\ \vdots & \vdots & \vdots & & \vdots \\ a_{n 1} & a_{n 2} & a_{n 2} & \ldots & a_{n n}\end{array}\right]$

B. Normalization of Pairwise Comparison Matrices

$$
\mathrm{W}=\left[\begin{array}{ccccc}
\frac{a_{11}}{\sum_{i=1}^{n} a_{i 1}} & \frac{a_{12}}{\sum_{i=1}^{n} a_{i 2}} & \cdots & \frac{a_{1 n}}{\sum_{i=1}^{n} a_{i n}} \\
\frac{a_{21}}{\sum_{i=1}^{n} a_{i 1}} & \frac{a_{22}}{\sum_{i=1}^{n} a_{i 2}} & \cdots & \frac{a_{2 n}}{\sum_{i=1}^{n} a_{i n}} \\
\vdots & & \cdots & \vdots \\
\frac{a_{n 1}}{\sum_{i=1}^{n} a_{n 1}} & \frac{a_{n 2}}{\sum_{i=1}^{n} a_{n 2}} & \cdots & \frac{a_{n n}}{\sum_{i=1}^{n} a_{n n}}
\end{array}\right]
$$

C. Calculate the Valute Eigen Vector
$\mathrm{B}=\left[\begin{array}{cccc}a_{11} \cdot \operatorname{ar}_{11} & a_{12} \cdot \operatorname{ar}_{21} & \ldots & a_{1 n} \cdot a r_{n 1} \\ a_{21} \cdot \operatorname{ar}_{11} & a_{22} \cdot \operatorname{ar}_{21} & \ldots & a_{2 n} \cdot a r_{n 1} \\ \vdots & \vdots & & \vdots \\ a_{n 1} \cdot a_{11} & a_{n 2} \cdot a_{21} & \ldots & a_{n n} \cdot a r_{n 1}\end{array}\right]$

Determine matric $\mathrm{C}$ by sum of the cell value in Volom in the same row Calculate Eigen Valuae $\left(\lambda_{\max }\right)$

$$
\lambda_{\text {max }}=\sum_{i=1}^{n} \frac{c_{i 1}}{\frac{a r_{i 1}}{n}}
$$

Calculate Consistency Index

$$
\mathrm{CI}=\left(\lambda_{\max }-\mathrm{n}\right) /(\mathrm{n}-1)
$$

\section{Consistency Ratio}

To calculate consistency ratio, the value of random index by refer to random index matric, and see Table 1.

$\mathrm{CR}=\mathrm{CI} / \mathrm{RI}$ 
The $6^{\text {th }}$ International Seminar on Science and Technology (ISST) 2020

July $25^{\text {th }}, 2020$, Institut Teknologi Sepuluh Nopember, Surabaya, Indonesia

\begin{tabular}{|c|l|c|c|c|c|c|c|c|c|}
\hline \multirow{2}{*}{ No } & \multirow{2}{*}{ Respondent } & $\begin{array}{c}\text { CR } \\
\text { Criterion }\end{array}$ & $\begin{array}{c}\text { CR - Alternative } \\
\text { Electricity } \\
\text { Tariff }\end{array}$ & $\begin{array}{c}\text { Funding } \\
\text { F }\end{array}$ & $\begin{array}{c}\text { C } \\
\text { GH }\end{array}$ & $\begin{array}{c}\text { D } \\
\text { Fuel } \\
\text { Source }\end{array}$ & $\begin{array}{c}\text { E } \\
\text { Effect to } \\
\text { system }\end{array}$ & $\begin{array}{c}\text { F } \\
\text { Project } \\
\text { Duration }\end{array}$ & Remarks \\
\hline 2 & AP & $8.6 \%$ & $8.1 \%$ & $4.9 \%$ & $0.0 \%$ & $6.8 \%$ & $4.1 \%$ & $4.5 \%$ & $\begin{array}{l}\text { All CR is accepted, continue to } \\
\text { Fuzzy AHP }\end{array}$ \\
\hline 3 & MI & $9.6 \%$ & $6.4 \%$ & $6.6 \%$ & $4.5 \%$ & $5.7 \%$ & $9.4 \%$ & $8.2 \%$ & $\begin{array}{l}\text { All CR is accepted, continue to } \\
\text { Fuzzy AHP }\end{array}$ \\
\hline 4 & AR & $9.9 \%$ & $7.4 \%$ & $7.4 \%$ & $0.0 \%$ & $8.1 \%$ & $8.1 \%$ & $6.7 \%$ & $\begin{array}{l}\text { All CR is accepted, continue to } \\
\text { Fuzzy AHP }\end{array}$ \\
\hline 5 & RS & $9.3 \%$ & $8.4 \%$ & $7.9 \%$ & $0.0 \%$ & $8.6 \%$ & $9.6 \%$ & $8.7 \%$ & $\begin{array}{l}\text { All CR is accepted, continue to } \\
\text { Fuzzy AHP }\end{array}$ \\
\hline 6 & $\begin{array}{l}\text { SW (New } \\
\text { Zealand) }\end{array}$ & $8.9 \%$ & $6.3 \%$ & $6.6 \%$ & $4.5 \%$ & $6.1 \%$ & $8.0 \%$ & $3.8 \%$ & $\begin{array}{l}\text { All CR is accepted, continue to } \\
\text { Fuzzy AHP }\end{array}$ \\
\hline
\end{tabular}

Figure 4. Recapitulation Consistency Ration of Criterion and Alternative to be used for Fuzzy AHP.

\begin{tabular}{|c|c|c|c|c|c|c|c|c|c|c|c|c|c|c|c|}
\hline \multirow{5}{*}{ Alternative } & \multicolumn{13}{|c|}{ Criterion } & \multirow{5}{*}{$\begin{array}{l}\text { Total } \\
\text { Value }\end{array}$} & \multirow{5}{*}{ Rank } \\
\hline & Criterion & \multirow{2}{*}{\multicolumn{2}{|c|}{$\begin{array}{c}\text { A } \\
\text { Electricity } \\
\text { Tariff }\end{array}$}} & \multicolumn{2}{|c|}{$\begin{array}{c}\text { B } \\
\text { Funding }\end{array}$} & \multicolumn{2}{|c|}{$\begin{array}{c}\mathrm{C} \\
\mathrm{GHG}\end{array}$} & \multicolumn{2}{|c|}{$\begin{array}{c}\text { D } \\
\text { Source of } \\
\text { Fuel }\end{array}$} & \multicolumn{2}{|c|}{$\begin{array}{c}\text { E } \\
\text { Efect to } \\
\text { System }\end{array}$} & \multicolumn{2}{|c|}{$\begin{array}{c}\text { F } \\
\text { Project } \\
\text { Duration }\end{array}$} & & \\
\hline & Weight & & & \multicolumn{2}{|c|}{0.0819} & \multicolumn{2}{|c|}{0.2387} & \multicolumn{2}{|c|}{0.1924} & \multicolumn{2}{|c|}{0.2989} & \multicolumn{2}{|c|}{0.0396} & & \\
\hline & Rank & \multicolumn{2}{|c|}{4} & \multicolumn{2}{|c|}{5} & \multicolumn{2}{|c|}{2} & \multicolumn{2}{|c|}{3} & \multicolumn{2}{|c|}{1} & \multicolumn{2}{|c|}{6} & & \\
\hline & & $\mathbf{W}$ & Rank & $\mathbf{W}$ & Rank & $\mathrm{W}$ & Rank & $\mathbf{W}$ & Rank & W & Rank & W & Rank & & \\
\hline I - PLTD & & \begin{tabular}{l|l|}
0.0510 \\
\end{tabular} & 4 & 0.4221 & 1 & 0.0459 & 4 & 0.0636 & 4 & 0.3857 & 2 & 0.3018 & 2 & 0.1926 & 4 \\
\hline II - PLTS & & 0.3572 & 2 & 0.3504 & 2 & 0.3199 & 2 & 0.2742 & 2 & 0.1277 & 3 & 0.4467 & 1 & 0.2667 & 2 \\
\hline III - ORC & & 0.4106 & 1 & 0.1702 & 3 & 0.3274 & 1 & 0.2225 & 3 & 0.0580 & 4 & 0.1993 & 3 & 0.2211 & 3 \\
\hline IV - PLTA & & 0.1812 & 3 & 0.0574 & 4 & 0.3068 & 3 & 0.4397 & 1 & 0.4286 & 1 & 0.0521 & 4 & 0.3196 & 1 \\
\hline
\end{tabular}

Figure 5. Recapitulation of Weight and Rank of Each Criterion and Alternative.

After obtaining a consistency test value, only respondents who passed the consistency test $\leq 10 \%$ [4] for all 7 questionnaires will proceed to the Fuzzy AHP stage. AHP Scale and Fuzzy AHP Triangular Fuzzy Number can see Table 2. Data from several respondents who have been changed to the TFN scale are then combine by using the geometric mean. This is done for each comparison of criteria and each alternative comparison based on criteria.

$$
G=\sqrt[n]{X_{1 . .} X_{2 \ldots} X_{3 \ldots . .} X_{n}}
$$

The data of geometric mean results will be used in fuzzy AHP through stages below based on the formula.

1) Calculate the Value of Fuzzy Synthetic Extent (Si)

$$
\mathrm{Si}=\sum_{j=1}^{m} M_{g_{i}}^{j} \otimes\left[\sum_{i=1}^{n} \sum_{j=1}^{m} M_{g_{i}}^{j}\right]^{-1}
$$

2) Defuzzification [5]

$$
\mathrm{DM} i=\frac{((u i-l i)+(m i-l i))}{3}
$$

\section{3) Normalization of Defuzzification Value}

$$
\mathrm{W}=\frac{\mathrm{DM} i}{\sum_{i=1}^{n} \mathrm{DM} i}
$$

The purpose of this weight normalization is to change the values in the vector to be analog weights and consist of nonfuzzy numbers. By having the highest weight vector normalization values, a ranking of several alternatives can be made, and the best alternative can be selected.

\section{RESEARCH METHOD}

The flow diagram of the selection process for electrical energy sources is shown in Figure 1.

\section{VERIFICATION OF HYDRO POWER PLANT WATER BALANCE CAPACITY AND AFFECT CANAL LINING PROJECT}

\section{A. Determination of Laron Hydro Power Plant Generating Coefficient}

After verification in Larona hydro power plant (PLTA Larona) by taking some data, the generating coefficient should be change from 1.12 to 1.22 . It is also forecasted that when 148 cumecs water is consumed by Larona hydro power plant, its power generation should be increased from 165.7 MW to $180 \mathrm{MW}$.

\section{B. Determination of Laoran HPP Capacity After Canal Lining}

After testing of Larona Hydro Power Plant running 180 MW for about 4 hours in 10 July 2019, it is confirmed that Larona Hydro Power Plant can produce $180 \mathrm{MW}$ continuously. Water Balance Hydro Power Plant Generation after Canal Lining can see Table 4.

\section{PT Vale Indonesia Power Generations and Loads}

After canal lining increase hydro power plant water balance generating capacity, the Soroako RKEF project team together with Utilities team can determine the size of PTVI power generation and loads in 2019 and to forecast the power 
The $6^{\text {th }}$ International Seminar on Science and Technology (ISST) 2020

July $25^{\text {th }}, 2020$, Institut Teknologi Sepuluh Nopember, Surabaya, Indonesia

generation and loads in 2023. Figure 3 shown that in 2023, PTVI require additional power $20 \mathrm{MW}$.

\section{Criterion and Alternative for Power Plant Selection}

Several literatures are used to define the initial criterion [6][7]] and alternative [8]. Based on the results of discussions with several experts, it was decided to select some of the criterion and alternative that are suitable to be used for additional power Soroako RKEF. The selected criterion and alternatives are shown in Figure $\mathrm{s}$ for further processing for the selection of power plants using fuzzy AHP. Analytic Hierarchy Process Scheme for Selection of Alternative Power Plant can see Figure 2.

\section{FUZZY AHP ANALYSIS}

The questionnaire was distributed to 10 respondents whom has expertise in the fields of energy and electricity. From the 10 respondents, only 6 respondents whose questionnaire passed $\mathrm{CR} \leq 10 \%$ in the both criteria and alternative. The consitency ration is shown in Figure 4.

The comparison matrice in AHP scale of each questnionaire of criterion and alternative then to be converted in TFN by refer to Table 2 as refernce, after that geometric mean (3) is calculated to combine the evaluation from several respondent. The fuzzy synthetic extent (8), defuzzification (9), and normalisation 10) is calculated to find the final value of each alternative to get rank of priority and the best alternative as shown in Figure 5.

Project. but of course alternative hydropower has managerial consequence, they are:

a. Requires an additional PT Vale Indonesia workforce for operations and maintenance.

b. Large investment costs will certainly affect the company's cash flow and EBITDA in the future.

c. Most of the hydropower plants that are built are in the PT Vale Indonesia contract of work, however, some of the land is owned or managed by local residents so that it requires land acquisition which usually has its own constraints and challenges.

d. Need a flood control system if high rainfall intensity happened that exceeds the dam's reservoir capacity or damage to the dam due to the earthquake.

e. Making the dam will certainly sunk some village roads, so that it will cause new problems that the company needs to overcome.

f. Surrounding communities certainly want to get benefit from the existence of hydropower through the distribution of CSR funds.

\section{CONCLUSION AND RECOMMENDATION}

\section{A. Conclusion}

Conclusion among other;(1)The priority order of the 6 criteria used starting from the highest priority are:(a)Effects on operating systems, process plants and utilities; (b)Greenhouse Gases; (c) Resource availability; (d) Electricity Rates or LCOE; (e)Sources of funding; (f)Project Duration; (2)Hydro power plant gets the highest ranking or priority from the total result of merging priority of criteria and alternative. The ranking order starting from the highest priority is PLTA, PLTS, ORC and the last is PLTD; (3)Hydropower plant is the best alternative based on this study, one of the main causes is because hydropower get highest rank in criterion effect on the operating system and plant utilities (the criteria that has the highest weight), this provides information that the continuity of the operation of the plant process and the stability of the electrical system becomes very important and in accordance with the operating philosophy of the existing Furnace and new RKEF.

\section{B. Recommendation}

Recommendation among ather:(1)Hydropower plant is the best alternative from this study, while the constraints that will be faced by hydropower plant is high investment costs, furthermore if PT Vale Indonesia finds it difficult to obtain funds to finance the project, PT Vale Indonesia can switch to the alternative with the second highest priority, alternative II (PLTS). In this PLTS alternative, PT Vale Indonesia doesn't have to spend investment funds because the PLTS will be built by other private companies and PT Vale Indonesia will lease the company's generation equipment in the form of electricity tariffs per kwh; (2)Considering that hydropower development requires a long time, and in this study it is assumed that AMDAL and other government licenses are proceeding smoothly, therefore it is expected to be able to immediately take care of these licenses so that the problems can be overcome immediately;(3)Testing the ability of the Larona hydropower channel after canal lining has shown satisfactory results, but the condition of the aging Larona Canal structure needs to be strengthened immediately. For this reason, the Larona Canal strengthening project needs to be continued and completed; (4) It is necessary to install more accurate water flow measurement on the Larona canal, additional water discharge from the Patingko river, additional water debit from the Balambano river, and batubesi dam spillway, so that PTVI can get more accurate data regarding water volume data.

\section{REFERENCES}

[1] PT. Vale. Indonesia Tbk, "Dedicating Through Ages Optimizing Opportunities," Jakarta, 2018.

[2] Menteri Lingkungan Hidup. dan Kehutanan R. Indonesia, Peraturan Menteri Lingkungan Hidup dan Kehutanan Republik Indonesia Nomor P.15/MENLHK/ SETJEN/KUM.1/4/2019 Tentang Baku Mutu Emisi Pembangkit Listrik Tenaga Termal. Jakarta: Menteri Lingkungan Hidup dan Kehutanan Republik Indonesia, 2019.

[3] D. Chang, "Applications of the extent analysis method on fuzzy AHP," Eur. J. Oper. Res., vol. 95, pp. 649-655, 1996.

[4] T. L. Saaty and L. G. Vargas, Models, Methods, Concepts \& Applications of the Analytic Hierarchy Process, 1st ed. New York: Springer Science + Business Media, 2001 .

[5] Y. Anshori, "Pendekatan triangular fuzy number dalam metode analytic heirarchy process," J. Ilm. Foristek, vol. 2, no. 1, pp. 126-135, 2012.

[6] W. Parsson, "Energy Source Selection Study," Sydney, Australia, 2020.

[7] B. \& Veatch, "Energy Source Selection Study," 2020

[8] Z. Syahril and I. Abadi, "Analysis of Solar Potential for Electricity Generation in Pt. Vale Indonesia Tbk. Sorowako," in AIP Conference Proceedings, 2019, vol. 2088, no. 1, p. 020014, doi: 10.1063/1.5095266. 